\title{
Effects of diet and gliclazide on the haemostatic system of non-insulin-dependent diabetics
}

\author{
R C PATON, P B A KERNOFF, J K WALES, G P MCNICOL
}

\begin{abstract}
The effect of the sulphonylurea gliclazide on tests of haemostatic function was studied in 14 newly diagnosed non-insulin-dependent diabetics. After two months' treatment with diet alone 11 of the 14 were given gliclazide; the three others remained on dietary treatment. Compared with pretreatment values, significant reductions in platelet retention, factor VIII-related antigen, factor VIII coagulant activity, and plasma heparin neutralising activity accompanied a fall in the plasma glucose concentration due to either diet alone or diet and gliclazide.

The beneficial effects of gliclazide on platelet abnormalities seem likely to be due to its hypoglycaemic action rather than to any direct effect on haemostatic function.
\end{abstract}

\section{Introduction}

Abnormalities of platelet function and of the coagulation and fibrinolytic systems occur in association with diabetes mellitus. ${ }^{12}$ The effect of the degree of metabolic control of diabetes on these tests of haemostasis has received little attention, though adrenaline-induced platelet aggregation ${ }^{3}$ and factor VIII function and the possible influence of improved glycaemic control brought about by this sulphonylurea. We therefore assessed for one year the effects of diet and gliclazide on a panel of haemostatic tests in patients with non-insulin-dependent diabetes.

\section{Patients and methods}

Fourteen newly diagnosed non-insulin-dependent diabetics completed the study. Table I gives their clinical details. Their mean age was $59 \cdot 1$ (range 42-70) years. Two patients had exudative retinopathy and two had symptoms of peripheral neuropathy at the time of diagnosis, the remainder having no symptoms or signs of vascular disease. Diabetes mellitus was diagnosed on the basis of a $50 \mathrm{~g}$ two-hour glucose tolerance test using the criteria proposed by Keen et al. ?

All patients were seen at regular intervals by a dietitian and were educated to follow a conventional carbohydrate-restricted diet After eight weeks they underwent a second glucose tolerance test. If the two-hour blood glucose concentration exceeded $6 \mathrm{mmol} / 1$ (108 $\mathrm{mg} /$ $100 \mathrm{ml}$ ) gliclazide was prescribed in addition to the diet, the dose being adjusted to give optimal control of blood glucose concentrations. No other drugs were prescribed during the study. The patients were asked not to take aspirin-containing compounds and were given paracetamol as a substitute.

After informed consent had been obtained patients were reviewed

TABLE I-Clinical details of diabetics studied

\begin{tabular}{|c|c|c|c|c|c|c|c|}
\hline \multirow{2}{*}{$\begin{array}{c}\text { Case } \\
\text { No }\end{array}$} & \multirow{2}{*}{$\underset{\text { (years) }}{\text { Age }}$} & \multirow{2}{*}{ Sex } & \multirow{2}{*}{ Complications } & \multicolumn{3}{|c|}{ "o ideal body weight* at: } & \multirow{2}{*}{$\begin{array}{l}\text { Dose of } \\
\text { gliclazide } \\
\text { (mg/day) }\end{array}$} \\
\hline & & & & Onset & 2 months & 12 months & \\
\hline \multicolumn{8}{|c|}{ Treated by diet and gliclazide } \\
\hline 1 & 55 & $\mathrm{~F}$ & & 141 & 132 & 126 & 80 \\
\hline 2 & 62 & $\mathrm{~F}$ & & 112 & 103 & 103 & 80 \\
\hline 3 & 70 & $M$ & & 107 & 101 & 101 & 160 \\
\hline 4 & 61 & M & Peripheral neuropathy & 114 & 111 & 120 & 240 \\
\hline 5 & 61 & $\mathrm{~F}$ & & 156 & 141 & 147 & 160 \\
\hline 6 & 42 & $\mathrm{~F}$ & & 100 & 99 & 103 & 240 \\
\hline 7 & 55 & $M$ & Peripheral neuropathy & 123 & 110 & 110 & 80 \\
\hline 8 & 64 & $\mathrm{M}$ & Exudative retinopathy & 106 & 105 & 109 & 240 \\
\hline 9 & 68 & $\mathrm{~F}$ & & 111 & 106 & 107 & 320 \\
\hline 10 & 66 & $\mathrm{~F}$ & & 128 & 122 & 126 & 120 \\
\hline 11 & 65 & $\mathrm{M}$ & Exudative retinopathy & 101 & 103 & 107 & 160 \\
\hline \multicolumn{8}{|c|}{ Treated by diet alone } \\
\hline 12 & 56 & M & & 103 & 102 & 105 & \\
\hline 13 & 55 & $M$ & & 120 & 107 & 105 & \\
\hline 14 & 47 & $M$ & & 110 & 111 & 118 & \\
\hline
\end{tabular}

*Calculated using Metropolitan Life Assurance Co tables.

ristocetin cofactor activity ${ }^{4}$ have been reported to be reduced when diabetics were intensively treated with diet and insulin. Recently, the sulphonylurea gliclazide was introduced to clinical practice in the United Kingdom. This drug has been claimed to reduce platelet retention and aggregation when given to patients with maturity-onset diabetes, ${ }^{5} 6$ but studies have not distinguished between a specific drug-induced effect on platelet

\footnotetext{
University Department of Medicine, General Infirmary, Leeds LS1 3EX

R C PATON, MRCP, lecturer

P B A KERNOFF, MD, MRCP, lecturer (now consultant haematologist, Royal Free Hospital, London)

J K WALES, MD, FRCP, senior lecturer

G P MCNICOL, MD, PHD, professor
}

at two-monthly intervals throughout the study, when non-fasting venous blood was removed using a 19-gauge butterfly cannula. Blood was obtained at the same time at each visit (one to two hours after breakfast).

Blood glucose concentration was measured by a glucose oxidase method, platelet count with a Coulter Thrombocounter, platelet retention to glass beads by a modification ${ }^{6}$ of Salzman's method, factor VIII coagulant activity by a one-stage clotting assay, ${ }^{8}$ and factor VIII-related antigen by immunoelectrophoresis. ${ }^{9}$ Euglobulin clot lysis time was measured by the method of $\mathrm{Blix}^{10}$ (results expressed as arbitrary units ${ }^{11}$, fibrinogen concentration by the method of Ratnoff and Menzie, ${ }^{12}$ antithrombin III concentration by immunodiffusion, ${ }^{13}$ heparin neutralising activity of platelet-poor plasma by a heparinthrombin clotting time assay, ${ }^{14}$ and $\beta$-thromboglobulin concentration using a radioimmunoassay provided by the Radiochemical Centre (Amersham, England). Results for factor VIII and antithrombin III were expressed as the percentage of the results obtained in a normal plasma pool from 20 healthy male controls. Serum gliclazide con- 
centrations were measured by gas-liquid chromatography. ${ }^{15}$ Platelet retention and euglobulin lysis times were measured immediately after blood sampling; the remaining tests were performed on samples frozen and stored at $-70^{\circ} \mathrm{C}$.

Results were compared with pretreatment values using the Wilcoxon rank sign test for paired samples.

\section{Results}

The mean percentage ideal body weight for height at diagnosis was $116.7 \pm$ SEM $2.5 \%$ and after two months' dietary treatment had fallen significantly to $110 \pm 2.5 \%(\mathrm{p}<0.01)$. By the end of the study, however, it had increased significantly to $113 \pm 3.4 \%$ compared with the mean at two months $(p<0.01)$.

Three patients responded to dietary restriction alone and remained well controlled at the end of the study (mean postprandial plasma glucose concentration $4.3 \mathrm{mmol} / 1(77 \mathrm{mg} / 100 \mathrm{ml}))$. After two months the remaining 11 diabetics were not satisfactorily controlled by diet alone and gliclazide was introduced, daily doses ranging from 80 to $320 \mathrm{mg} /$ day. One patient withdrew from the study at the onset of gliclazide treatment because of dyspepsia (superficial gastritis shown by gastroscopy), which also recurred when another sulphonylurea,

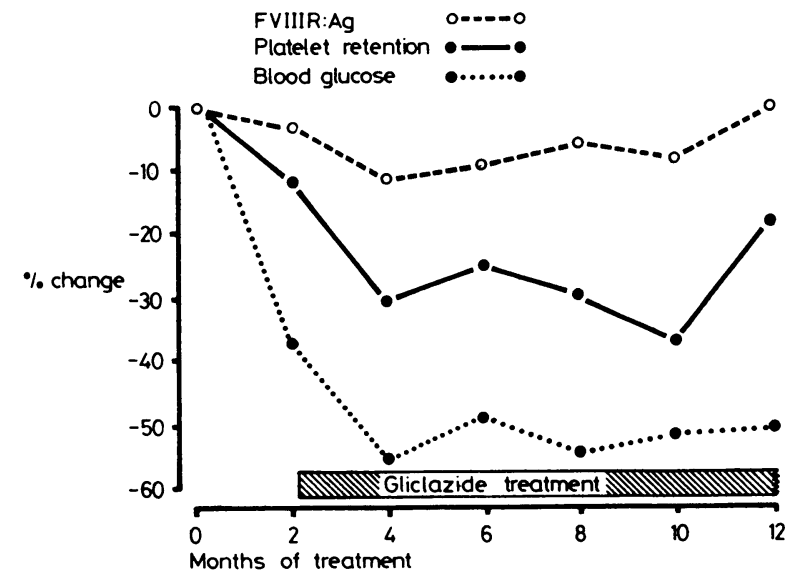

Percentage changes in mean blood glucose concentration, platelet retention, and factor VIII-related antigen (FVIIIR:Ag) compared with pretreatment values in 11 diabetics treated with diet for 12 months and gliclazide from the second to the twelfth month.

TABLE II-Laboratory results in the 11 diabetics treated with diet for 12 months and with gliclazide from two to 12 months. Values are means $( \pm S E M)$

\begin{tabular}{|c|c|c|c|c|c|c|c|}
\hline & \multicolumn{7}{|c|}{ Months of treatment } \\
\hline & 0 & 2 & 4 & 6 & 8 & 10 & 12 \\
\hline Blood glucose $(\mathrm{mmol} / \mathrm{l})$ & $14 \cdot 7$ & $9 \cdot 3+$ & $6 \cdot 6 \pm$ & $7.5 \pm$ & $6.7 \pm$ & $7 \cdot 0 \pm$ & $7.3 \pm$ \\
\hline Serum gliclazide $(\mathrm{mg} / \mathrm{l})$ & & $(0 \cdot 8)$ & $5 \cdot 3$ & $\begin{array}{l}(0.6) \\
5 \cdot 0\end{array}$ & $\begin{array}{l}(0.5) \\
5.7 \\
(1.1)\end{array}$ & 4.8 & 5.3 \\
\hline Platelet retention $\left({ }^{\circ},\right)$ & 35.5 & $31 \cdot 3$ & $24 \cdot 7^{*}$ & $26 \cdot 7^{*}$ & $\begin{array}{l}(1.1) \\
25 \cdot 0^{*}\end{array}$ & $22 \cdot 3+$ & $\begin{array}{l}(1 \cdot 0) \\
29 \cdot 2\end{array}$ \\
\hline Fo VUU & $(3 \cdot 1)$ & $(2.5)$ & $(2 \cdot 1)$ & $(3 \cdot 3)$ & $(2 \cdot 7)$ & $(2 \cdot 0)$ & $(4 \cdot 1)$ \\
\hline Factor VIII-related antigen $\left({ }^{\circ}, 0\right)$ & $\begin{array}{l}165 \\
(16)\end{array}$ & $\begin{array}{l}161 \\
(19)\end{array}$ & $(22)$ & $\begin{array}{l}149 \\
(24)\end{array}$ & $\begin{array}{l}1166 \\
(23)\end{array}$ & $\begin{array}{l}151 \\
(29)\end{array}$ & $\begin{array}{l}165 \\
(34)\end{array}$ \\
\hline Factor VIII coagulant activity $(\%)$ & 172 & $129^{*}$ & $130^{*}$ & $112 \dagger$ & $131^{*}$ & 176 & 151 \\
\hline Heparin neutralising activity $(\mathrm{U} / \mathrm{ml})$ & 0.21 & $0 \cdot 16$ & $0 \cdot 14^{*}$ & $0 \cdot 11^{*}$ & $0 \cdot 14^{*}$ & $0.12^{*}$ & $0.13^{*}$ \\
\hline Euglobulin lysis time (U) & $(0.04)$ & $(0.03)$ & $(0.02)$ & $(0.01)$ & $\begin{array}{l}(0.03) \\
12.9\end{array}$ & $(0.02)$ & $(0.01)$ \\
\hline & $\begin{array}{l}13.2 \\
(0 \cdot 4)\end{array}$ & $\begin{array}{l}12 \cdot 1 \\
(0 \cdot 6)\end{array}$ & $\begin{array}{l}12 \cdot 6 \\
(0 \cdot 3)\end{array}$ & $\begin{array}{l}12 \cdot 7 \\
(0 \cdot 3)\end{array}$ & $(0 \cdot 3)$ & $(0.5)$ & $(0.4)$ \\
\hline$\beta$-thromboglobulin $(\mu \mathrm{g} / \mathrm{l})$ & $56 \cdot 2$ & 68.9 & $43 \cdot 4$ & $77 \cdot 9$ & $64 \cdot 2$ & $63 \cdot 2$ & 44.1 \\
\hline Fibrogen $(\mathrm{g} / \mathrm{l})$ & 3.00 & $2 \cdot 72$ & $\begin{array}{l}(6.8) \\
2.94\end{array}$ & $\begin{array}{c}(18.1) \\
2.81\end{array}$ & $\begin{array}{l}(17.3) \\
2.70\end{array}$ & $\begin{array}{l}(10 \cdot 1) \\
2 \cdot 95\end{array}$ & $\begin{array}{l}(6.0) \\
2.77\end{array}$ \\
\hline Antithrombin III $\left({ }^{\circ}, 0\right)$ & $\begin{array}{l}(0.18) \\
107.8\end{array}$ & $\begin{array}{l}(0.17) \\
111.4\end{array}$ & $\begin{array}{l}(0 \cdot 16) \\
112 \cdot 0\end{array}$ & $\begin{array}{l}(0 \cdot 21) \\
105 \cdot 0\end{array}$ & $\begin{array}{l}(0.24) \\
98 \cdot 9\end{array}$ & $\begin{array}{l}(0 \cdot 18) \\
99 \cdot 9\end{array}$ & $\begin{array}{l}(0.19) \\
100.5\end{array}$ \\
\hline 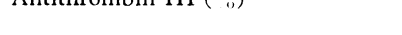 & $(4 \cdot 6)$ & $(4 \cdot 5)$ & $(5 \cdot 8)$ & $(4 \cdot 6)$ & $\begin{array}{l}98 \cdot 9 \\
(4 \cdot 7)\end{array}$ & $(5 \cdot 6)$ & (3.9) \\
\hline
\end{tabular}

${ }^{*} \mathrm{p}-0.05,+\mathrm{p}<0.01$ compared with pretreatment values.

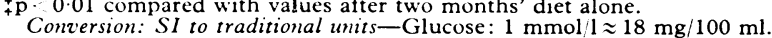

TABLE III-Laboratory results in the three patients treated with diet alone

\begin{tabular}{|c|c|c|c|c|c|c|c|c|}
\hline & \multirow{2}{*}{$\begin{array}{l}\text { Case } \\
\text { No }\end{array}$} & \multicolumn{7}{|c|}{ Months of treatment with diet alone } \\
\hline & & 0 & 2 & 4 & 6 & 8 & 10 & 12 \\
\hline \multirow[t]{3}{*}{ Blood glucose $(\mathrm{mmol} / \mathrm{l})$} & $\left\{\begin{array}{l}12 \\
13\end{array}\right.$ & $\begin{array}{l}14 \cdot 4 \\
10 \cdot 1\end{array}$ & $\begin{array}{l}5 \cdot 6 \\
5 \cdot 0\end{array}$ & $\begin{array}{l}6 \cdot 1 \\
4 \cdot 5\end{array}$ & $\begin{array}{l}5 \cdot 1 \\
4 \cdot 0\end{array}$ & $\begin{array}{l}7 \cdot 7 \\
3 \cdot 5\end{array}$ & $\begin{array}{l}5 \cdot 2 \\
3 \cdot 2\end{array}$ & $\begin{array}{l}2 \cdot 6 \\
4 \cdot 0\end{array}$ \\
\hline & 14 & $22 \cdot 0$ & $4 \cdot 0$ & $5 \cdot 2$ & $\begin{array}{l}4 \cdot 0 \\
4 \cdot 8\end{array}$ & 3.6 & 4.5 & $\begin{array}{l}4 \cdot 0 \\
7 \cdot 7\end{array}$ \\
\hline & 112 & $48 \cdot 0$ & 16.0 & 17.0 & $20 \cdot 0$ & $8 \cdot 0$ & 26.0 & $24 \cdot 0$ \\
\hline \multirow[t]{3}{*}{ Platelet retention ("u) } & $\{13$ & $17 \cdot 0$ & 27.9 & $25 \cdot 0$ & $24 \cdot 0$ & $17 \cdot 0$ & $8 \cdot 0$ & $20 \cdot 0$ \\
\hline & 14 & 17.0 & $20 \cdot 0$ & 9.0 & 8.0 & 17.0 & 14.0 & 14.0 \\
\hline & 112 & 147 & 105 & 88 & 116 & 104 & 98 & 126 \\
\hline \multirow[t]{3}{*}{ Factor VIII-related antigen (" } & $\{13$ & 123 & 136 & 127 & 91 & 150 & 162 & 156 \\
\hline & 14 & 202 & 100 & 112 & 103 & 109 & 171 & 175 \\
\hline & 12 & 175 & 195 & 140 & 86 & 102 & 113 & 98 \\
\hline \multirow[t]{2}{*}{ Factor VIII coagulant activity $\left({ }_{0}^{\prime}\right)$} & $\{13$ & 108 & 98 & 121 & 121 & 93 & 120 & 123 \\
\hline & 14 & 219 & 126 & 135 & 155 & 140 & 128 & 163 \\
\hline \multirow{2}{*}{ Heparin neutralising activity $(\mathrm{U} / \mathrm{ml})$} & $\{13$ & $\begin{array}{l}0 \cdot 172 \\
0 \cdot 194\end{array}$ & $\begin{array}{l}0 \cdot 112 \\
0 \cdot 120\end{array}$ & 0.136 & $0 \cdot 102$ & $0 \cdot 105$ & 0.110 & 0.136 \\
\hline & $\left\{\begin{array}{l}13 \\
14\end{array}\right.$ & $\begin{array}{l}0.194 \\
0.304\end{array}$ & $\begin{array}{l}0.120 \\
0.118\end{array}$ & $\begin{array}{l}0.218 \\
0.290\end{array}$ & $\begin{array}{l}0.204 \\
0.550\end{array}$ & $\begin{array}{l}0.092 \\
0.222\end{array}$ & $\begin{array}{l}0.128 \\
0.180\end{array}$ & $\begin{array}{l}0.124 \\
0.125\end{array}$ \\
\hline
\end{tabular}

Conversion: SI to traditional units-Glucose: $1 \mathrm{mmol} / 1 \approx 18 \mathrm{mg} / 100 \mathrm{ml}$.

glipizide, was given. Two patients had symptoms of hypoglycaemia, which were abolished when the dose of gliclazide was reduced.

Table II summarises the laboratory findings in the 11 patients treated with diet and gliclazide. After two months of diet alone significant reductions were observed in plasma glucose concentration and factor VIII coagulant activity. After the introduction of gliclazide there was a further significant fall in plasma glucose concentration.
Platelet retention, factor VIII coagulant activity, factor VIII-related antigen, and plasma heparin neutralising activity were reduced significantly compared with pretreatment values. Mean serum gliclazide concentrations remained constant throughout the treatment period, and the remaining haemostatic tests showed no significant changes. When percentage changes compared with pretreatment values were plotted (figure) the changes in platelet retention and 
factor VIII-related antigen followed the same pattern as changes in postprandial plasma glucose concentrations.

Because of the small number of patients who were adequately controlled by diet alone, statistical analysis of this group was not possible. Nevertheless, reductions in mean platelet retention, factor VIII coagulant activity, factor VIII-related antigen, and heparin neutralising activity were observed (table III), while results of the remaining tests did not change.

\section{Discussion}

In this study satisfactory glycaemic control was achieved when gliclazide was added to the dietary treatment of newly diagnosed non-insulin dependent diabetics who were not adequately controlled with diet alone. Reduction of blood glucose concentrations was associated with changes in tests of haemostatic function-namely, a reduction in platelet retention, factor VIII coagulant activity, factor VIII-related antigen, and heparin neutralising activity. Smaller changes in these tests occurred after the two months of diet alone, which, with the exception of the change in factor VIII coagulant activity, failed to reach significance. Since the "ideal" weight was not achieved in all these patients, extending the dietary period might possibly have caused further falls in plasma glucose concentration with a corresponding improvement in these haemostatic tests.

Towards the end of the 12 months the results of the tests tended to return towards pretreatment values, whether the patients were treated by diet alone or by diet plus gliclazide. In the gliclazide-treated group mean drug concentrations remained constant, suggesting good compliance with treatment, but there was a significant increase in body weight and a slight rise in blood glucose concentrations at 12 months, which may imply that dietary habits deteriorated towards the end of the study.

Previous workers showed that treatment of maturity-onset diabetes with gliclazide resulted in reduction of platelet retention to glass beads and of adenosine-diphosphate-induced platelet aggregation. ${ }^{56}$ In those studies, however, such treatment also produced an improvement in plasma glucose concentrations, and it is therefore uncertain whether the changes in platelet function were due to the drug or to improved metabolic control. The present study appears to favour the latter hypothesis. Treatment by diet alone resulted in improvements in certain haemostatic tests, and falls in plasma glucose concentration were paralleled by a corresponding reduction in factor VIII-related antigen and platelet retention.

The biological implications of such changes are uncertain. Previous studies have shown that haemostatic abnormalities tend to be most pronounced in patients with diabetic vascular complications. ${ }^{12}$ If an abnormal haemostatic mechanism plays a part in the pathogenesis of diabetic angiopathies then a return of these tests towards normal might be expected to be beneficial. On the other hand, such abnormalities may be purely secondary to vascular damage. For example, in adequately controlled diabetes the highest concentrations of factor VIIIrelated antigen are generally found in diabetics with microvascular disease, but concentrations rise sharply during diabetic ketoacidosis and return towards normal after correction of the metabolic disturbance. ${ }^{16}$ Factor VIII-related antigen is produced by vascular endothelial cells, ${ }^{17}$ so it is possible that raised concentrations of this antigen during periods of poor diabetic control indicate vascular endothelial damage. Factor VIII coagulant activity, considered to be an acute-phase reactant, ${ }^{18}$ is not synthesised by endothelial cells. Raised factor VIII coagulant activity may therefore represent tissue injury also caused by the disordered carbohydrate and lipid metabolism in uncontrolled diabetes.

The ability of plasma to neutralise heparin is partly due to a factor released from platelets (platelet factor 4). Plasma values of both heparin neutralising activity ${ }^{19}$ and platelet factor $4^{20}$ have been reported to be increased in diabetes. A proportion of heparin neutralising activity, however, is contributed by $\alpha$-glycoproteins, ${ }^{21}$ which are also raised in diabetes. ${ }^{22}$ As plasma $\beta$-thromboglobulin and platelet factor 4 are released simultaneously from platelets ${ }^{23}$ the most likely explanation from the present study for a change in heparin neutralising activity during treatment would appear to be a change in $\alpha$-glycoprotein components.

In conclusion, the results of this study do not support the view that gliclazide per se exerts a beneficial effect on the haemostatic function of non-insulin-dependent diabetes. Nevertheless, control of plasma glucose concentrations by diet and gliclazide led to an improvement in some tests of coagulation and platelet function. Whether such changes lead to a reduction in diabetic vascular complications must await the results of controlled prospective clinical trials.

We thank Miss C Jackson and Mrs A Spencer for expert technical help and Servier Laboratories (UK) for providing the gliclazide tablets and for performing the serum gliclazide measurements.

\section{References}

${ }^{1}$ Bern MM. Platelet functions in diabetes mellitus. Diabetes 1978;27: 342-50.

2 Jones RL, Peterson CM. Hematologic alterations in diabetes mellitus. Am f Med 1981;70:339-52.

${ }^{3}$ Peterson CM, Jones RL, Koenig RJ, Melvin ET, Lehrman ML. Reversible hematologic sequelae of diabetes mellitus. Ann Intern Med $1977 ; 86: 425-9$

${ }^{4}$ Gonzalez J, Colwell JA, Sarji KE, Nair RMG, Sagel J. Effect of metabolic control with insulin on plasma von Willebrand activity (VIIIR:WF) in diabetes mellitus. Thromb Res 1980;17:261-6.

5 Rubinjoni Z, Turk Z, Coce F, Mustovic D, Maitre D, Skrabalo Z. Effect on platelet adhesiveness in diabetes after long-term treatment with a new oral hypoglycaemic agent, gliclazide. Curr Med Res Opin $1978 ; 8: 625-31$

${ }^{6}$ Ponari O, Civardi E, Megha S, Pini M, Portioli D, Dettori AG. Antiplatelet effects of long-term treatment with gliclazide in diabetic patients. Thromb Res 1979;16:191-203.

Keen H, Jarrett RJ, Alberti KGMM. Diabetes mellitus: a new look at diagnostic criteria. Diabetologia $1979 ; 16: 283-5$

${ }^{8}$ Breckenridge RT, Ratnoff OD. Studies on the nature of the circulating anticoagulant directed against antihemophilic factor: with notes on an assay for antihemophilic factor. Blood $1962 ; 20: 137-40$.

${ }^{9}$ Laurell C-B. Quantitative estimation of proteins by electrophoresis in agarose gel containing antibodies. Anal Biochem 1966;15:45-52.

10 Blix S. Studies on the fibrinolytic system in the euglobulin fraction of human plasma. Scand $\mathcal{F}$ Clin Lab Invest 1961 ;13,suppl 58:3-19.

${ }^{11}$ Alkjaersig N, Fletcher AP, Sherry S. Pathogenesis of the coagulation defect developing during pathological plasma proteolytic ("fibrinolytic") states. F Clin Invest 1962;41:917-34.

12 Ratnoff OD, Menzie C. A new method for the detection of fibrinogen in small samples of plasma. f Lab Clin Med $1951 ; 37: 316-20$.

${ }_{13}$ Mancini G, Carbonara AO, Heremans JF. Immunochemical quantification of antigens by single radial immunodiffusion. Immunochemistry 1965; $2: 235-54$.

14 Donati MB, Palester-Chlebowezk M, De Gaetano G. Platelet factor 4methods of study. Adv Exp Med Biol 1972;34:295-308.

15 Campbell DB, Andriaenssens P, Hopkins YW, Gordon B, Williams JRB. Pharmacokinetics and metabolism of gliclazide: a review. Royal Society of Medicine International Congress and Symposium Series 1980; No 20:71-81.

16 Paton RC. Haemostatic changes in diabetic coma. Diabetologia 1981;21: 172-7.

17 Jaffe EA, Hoyer LW, Nachman RL. Synthesis of antihemophilic factor antigen by cultured human endothelial cells. F Clin Invest 1973;52: 2757-64.

18 Brozovic M. Physiological mechanisms in coagulation and fibrinolysis. Br Med Bull 1978;33:231-8.

19 Chmielewski J, Farbiszewski R. Platelet factor 4 (PF4) release during platelet aggregation in diabetic patients. Thrombosis et Diathesis Haemorrhagica $1970 ; 24: 203-5$

${ }^{20}$ Zahavi J, Jones NAG, Betteridge DJ, et al. Platelet factor 4, $\beta$-thromboglobulin, malondialdehyde formation and blood lipids in patients with diabetes mellitus. Thromb Haemost 1979;42:334.

21 Andersen P, Godal HC. The antiheparin effect of $\alpha_{1}$-acid glycoprotein and platelet material evaluated by the heparin thrombin clotting time. Haemostasis $1977 ; 6: 339-46$.

22 Jonsson A, Wales JK. Blood glycoprotein levels in diabetes mellitus. Diabetologia 1976;12:245-50.

${ }^{23}$ Kaplan KL, Owen J. Plasma levels of $\beta$-thromboglobulin and platelet factor 4 as indices of platelet activation in vivo. Blood $1981 ; 57: 199-202$.

(Accepted 16 fuly 1981) 